\title{
Using the CNCPS model to evaluate forage supplements for grazing dairy cows
}

\author{
A.V. Chaves ${ }^{1}$ and E.S. Kolver ${ }^{2}$ \\ ${ }^{1}$ Unité Mixte de Recherches Production du Lait (UMRPL), Institut National de la Recherche \\ Agronomique (INRA) 35590, St-Gilles, France \\ ${ }^{2}$ Dexcel Limited, Private bag 3221, Hamilton, New Zealand
}

\begin{abstract}
The Cornell Net Carbohydrate and Protein System (CNCPS) model was used to evaluate pasture, maize, lotus, and sulla silage supplements for grazing dairy cows. Base data were obtained from a New Zealand study comparing six dietary treatments. Each treatment consisted of 10 cows and included one ad libitum pasture allowance treatment and a restricted pasture allowance treatment. These data plus digestion kinetic information were used as inputs to the CNCPS model to determine the first-limiting nutrient and to provide information concerning rumen digestion parameters. The value of these silages as either supplementary or complementary feeds for grazing dairy cows was identified.
\end{abstract}

KEY WORDS: dairy cows, lotus, maize, pasture, modelling, sulla

\section{INTRODUCTION}

Novel silages with different nutritional characteristics have been compared as feeds that could be used to either supplement, or complement, pasture diets for grazing dairy cows (Woodward et al., 2002). The silages had nutritive properties such as high levels of soluble carbohydrate, high metabolizable energy, and tannins thought to improve production. However, this study only measured feed input and production outputs, with no measurements of ruminal digestion or nutrient supply.

The Cornell Net Carbohydrate and Protein System (CNCPS) model has been shown to be useful for predicting the supply of nutrients on fresh pasture diets (Kolver et al., 1998). This paper describes how the CNCPS was used to understand the influence of novel silage supplements on nutrient supply of grazing dairy cows.

\footnotetext{
${ }^{1}$ Corresponding author: e-mail: chaves@st-gilles.rennes.inra.fr
} 


\section{MATERIAL AND METHODS}

The base trial was conducted in New Zealand and involved 60 cows in mid lactation (Woodward et al., 2002). Cows were allocated to six treatments and balanced for milksolids yield and liveweight measured during the uniformity period. The treatments and the actual dry matter intake (DMI) achieved were: 1. Pasture only - ad libitum allowance (allowance $50 \mathrm{~kg} \mathrm{DM} / \mathrm{cow}$ per day); 2. Pasture only - restricted allowance (allowance $25 \mathrm{~kg} \mathrm{DM} / \mathrm{cow}$ per day); 3. Pasture (restricted) + pasture silage ( $5 \mathrm{~kg} \mathrm{DM} / \mathrm{cow}$ per day); 4. Pasture (restricted) + maize silage ( $5 \mathrm{~kg} \mathrm{DM} /$ cow per day); 5. Pasture (restricted) + lotus silage (5 $\mathrm{kg} \mathrm{DM} / \mathrm{cow}$ per day) and 6. Pasture (restricted) + sulla silage (5 kg DM/cow per day).

The CNCPS model was used to provide an explanation for cow responses to the six dietary treatments. Inputs to the model included feed composition collected in this experiment; degradation rates for carbohydrate and protein from the CNCPS feed library and J.L. Burke (personal information), and cow parameters measured during the trial.

\section{RESULTS}

The CNCPS library parameters enabled diet composition to be generated and a prediction made of milk production. The model also generated estimates of microbial growth, nitrogen kinetics and passage rate (Table 1).

The ad libitum pasture and lotus silage treatments resulted in the highest milk production (actual and predicted; Table 1). Cows fed pasture and pasture with lotus or sulla silages were first-limited by the supply of metabolizable energy (ME), although metabolizable protein (MP) was the first-limiting nutrient with the pasture silage and maize silage treatments. The low crude protein (CP) content of pasture silage and maize silages lowered dietary CP compared to the pasture alone, lotus silage, and sulla silage treatments. Although the maize silage diet had the lowest CP concentration, it resulted in a high flow of microbial nitrogen from the rumen ( $277 \mathrm{~g} /$ day; $68 \%$ of MP) due to the high nonfibrous carbohydrate (NFC) content of the diet. This was comparable to the ad libitum pasture diet.

Diets with higher CP concentrations (full pasture and lotus silage treatments) resulted in a higher cost of urea synthesis and excretion and had more excess $\mathrm{N}$ excreted than the other treatments. All diets met the requirements for ruminal microbial nitrogen with a ruminal $\mathrm{N}$ balance ranging between $125-167 \%$ of requirements. 
Table 1. CNCPS predictions of nutrient composition, cow performance and rumen parameters of treatment diets. NFC, non-fibrous carbohydrates. DIP, degradable intake protein

\begin{tabular}{lcccccc}
\hline Feeding treatment & $\begin{array}{c}\text { Ad libitum } \\
\text { pasture }\end{array}$ & $\begin{array}{c}\text { Restricted } \\
\text { pasture }\end{array}$ & $\begin{array}{c}\text { Pasture } \\
\text { silage }\end{array}$ & $\begin{array}{c}\text { Maize } \\
\text { silage }\end{array}$ & $\begin{array}{c}\text { Lotus } \\
\text { silage }\end{array}$ & $\begin{array}{c}\text { Sulla } \\
\text { silage }\end{array}$ \\
\hline Total dry matter intake, kg DM cow/day & 18.5 & 12.5 & 17.0 & 16.6 & 17.2 & 15.7 \\
& & & & & & \\
Diet nutrient composition & & & & & & \\
metabolizable energy, MJ/kg DM & 9.67 & 10.24 & 9.95 & 10.03 & 9.84 & 9.42 \\
crude protein (CP), g/100g DM & 19.0 & 17.4 & 16.9 & 14.4 & 19.1 & 16.7 \\
soluble CP, \%CP & 55.0 & 55.0 & 53.6 & 55.4 & 53.3 & 54.8 \\
neutral detergent fibre, g/100 g DM & 55.9 & 47.5 & 47.3 & 46.6 & 44.0 & 48.3 \\
total NFC, g/100 g DM & 11.2 & 21.6 & 24.8 & 27.7 & 24.3 & 21.6 \\
actual milk, kg/day & 17.0 & 13.1 & 15.0 & 15.0 & 17.2 & 15.1 \\
& & & & & & \\
Performance predictions & & & & & & \\
ME allowable milk, $\mathrm{kg} /$ day & 20.5 & 11.0 & 19.3 & 19.2 & 19.2 & 15.1 \\
MP allowable milk, kg/day & 24.7 & 14.0 & 18.5 & 17.5 & 19.5 & 15.3 \\
& & & & & & \\
Rumen digestion, metabolism and passage & & & & & & \\
MP from bacteria, g/day & 1013 & 764 & 978 & 1038 & 953 & 873 \\
MP from undegradable feed, g/day & 980 & 447 & 615 & 485 & 752 & 567 \\
total DIP, \% CP & 78.0 & 79.7 & 75.3 & 78.1 & 75.9 & 77.7 \\
ruminal N balance, \% of req. & 160 & 146 & 146 & 125 & 167 & 151 \\
total bacterial nitrogen, g/day & 270 & 204 & 261 & 277 & 254 & 233 \\
urea cost, \% ME intake & 2.8 & 1.6 & 1.8 & 0.6 & 2.5 & 1.6 \\
excess N excreted, g/day & 221 & 101 & 150 & 94 & 190 & 124 \\
liquid passage rate, \% $\mathrm{h}^{-1}$ & 11.2 & 9.3 & 10.8 & 10.7 & 10.7 & 10.3 \\
pasture passage rate, \% $\mathrm{h}^{-1}$ & 6.51 & 5.54 & 6.46 & 6.42 & 6.45 & 6.20 \\
silage passage rate, \% $\mathrm{h}^{-1}$ & $\mathrm{NA}$ & $\mathrm{NA}$ & 5.02 & 5.30 & 5.83 & 4.73 \\
predicted ruminal $\mathrm{pH}$ & 6.37 & 6.23 & 6.46 & 6.46 & 6.34 & 6.46 \\
\hline
\end{tabular}

\section{DISCUSSION}

On commercial dairy farms in New Zealand, silages are generally used to supplement pasture during a pasture deficit or in more intensive dairying systems. However, with novel silages that contain high levels of soluble carbohydrate and include tannins, the value of these forages as complementary, rather than supplementary feeds, is of interest. This modeling project allowed a comparison of the relative value of a range of silages to either complement, or supplement, fresh pasture diets for dairy cows.

\section{Complementary effects}

The value of forage supplements to complement pasture can be determined by comparing the ad libitum pasture treatment with silage supplement diets. Ad libitum pasture provided more nutrients for greater milk production 
because cows grazing pasture had a greater DMI and pasture contained more $\mathrm{CP}$ compared to diets of restricted pasture and silages. As a result ME and MP supply were highest when cows were fed an ad libitum pasture diet.

The tannin effect of lotus and sulla silages was able to be modelled by using degradation rates of lotus and sulla determined in sacco. However, the degradable intake protein (DIP) content of the total diet was not changed markedly by the tannincontaining supplements. The lotus silage diet had a similar CP and DIP content compared to the ad libitum pasture treatment, and resulted in a similar loss of $\mathrm{N}$ as urea. Maize silage, which had a lower CP content, had a lower level of urea excretion. Silage diets had a minimal effect on the passage rate of pasture from the rumen when compared to the ad libitum pasture treatment. The milk production and nutrient supply results show that for cows fed well on pasture of medium quality, the forage silages tested in this experiment did not provide a complementary benefit to pasture.

\section{Supplementary effects}

The value of forage silages to supplement pasture can be evaluated by comparing the restricted pasture treatment with the silage supplement treatments. Increasing DMI by supplementing with silages increased ME and MP supply, and milk production. This was simply a function of a higher DMI, rather than an improved balance of nutrients as the pasture generally contained more ME and CP than the silage diets.

Milk production responses showed that the silages gave poor responses except for lotus silage. The greater milk response observed on the pasture and lotus silage diet may have been due to the effect of tannins on pasture protein, thereby increasing the supply of MP. However, the model predicted that MP was not the first-limiting nutrient for milk production on the lotus diet.The model was unable to explain the larger response observed to the lotus silage diet when compared to the other silage diets.

\section{CONCLUSIONS}

The CNCPS model was used to show that a range of silages could be used to supplement pasture diets, but that pasture, maize, lotus, and sulla silages did not confer complementary benefits when compared to an ad libitum pasture diet.

\section{REFERENCES}

Kolver E.S., Muller L.D., Barry M.C., Penno J.W., 1998. Evaluation and application of the Cornell Net Carbohydrate and Protein System for dairy cows fed diets based on pasture. J. Dairy Sci. 81, 2029-2039

Woodward S.L., Chaves A.V., Waghorn G.C., Laboyrie P.J., 2002. Supplementing pasture-fed dairy cows with pasture silage, maize silage, Lotus silage or sulla silage in summer- does it increase production? Proc. N. Z. Grassl. Assn. 64, 85-89 